\section{Reinventing Race, Colonization, and Globalisms across Deep Time: Lessons from the Longue Durée}

\author{
GERALDINE HENG
}

GERALDINE HENG is Perceval Associate Professor of English and Comparative Literature at the University of Texas, Austin, and the founder and codirector of the Global Middle Ages Project (G-MAP). The author of Empire of Magic: Medieval Romance and the Politics of Cultural Fantasy (Columbia UP, 2003), she is completing two new books, to be titled The Invention of Race in the European Middle Ages and England and the Jews: How Religion and Violence Created the First Racial State in the West. Her work last appeared in PMLA in 2011.

\section{IN JULY 1099, AFTER THREE YEARS OF LEVANTINE MILITARY ADVENTURE} DURING WHICH NEW LATIN CHRISTIAN COLONIES WERE FASHIONED AT

Edessa and Antioch, the transnational forces from Europe later known as the First Crusade finally captured their principal target: Jerusalem. ${ }^{1}$ Three eyewitness chronicles attest to the bloodbath that followed. Fulcher of Chartres, chaplain to one of the foremost Crusade leaders, estimated that "ten thousand were beheaded" at the Temple of Solomon alone (Chronicle 77). The anonymous author of the Gesta Francorum (The Deeds of the Franks) averred, "No-one has ever seen or heard of such a slaughter of pagans" (92). Raymond d'Aguiliers, chaplain to another Crusade leader, was effusive:

Some of the pagans were mercifully beheaded, others pierced by arrows plunged from towers, and yet others, tortured for a long time, were burned to death in searing flames. Piles of heads, hands, and feet lay in the houses and streets, and indeed there was a running to and fro of men and knights over the corpses.... [T]hese are few and petty details.... Shall we relate what took place there? If we told you, you would not believe us. So it is sufficient to relate that in the Temple of Solomon and the portico crusaders rode in blood to the knees and bridles of their horses. In my opinion, this was poetic justice.... Jerusalem was now littered with bodies. (Historia 127-28) ${ }^{2}$

The eyewitness chroniclers are awed at the magnitude and particulars of crusader carnage, but they register little concern at the bloodletting, let alone horror, outrage, or condemnation. Like the abhorrent digital content put online today by the ideologues of the so-called Islamic State, the words and images of the chroniclers are released without remorse and with an air of satisfaction. Soon after the sanguinary conquest and depopulation of the city, the invading forces repopulate Jerusalem, occupying emptied-out abodes and estates. A few years later, Fulcher rejoices in his Historia Hierosolymitana (History of the Expedition to Jerusalem) at the success of the expedition to Syria and Palestine, which has seized land from Muslims, Armenians, and Greeks and carved out four new overseas colonies, along with ports, towns, fortifications, and hinterlands, for the West:

(C) 2015 GERALDINE HENG

PMLA 130.2 (2015), published by the Modern Language Association of America 
Consider, I pray, and reflect how in our time God has transformed the West into the East. For we who were Occidentals now have been made Orientals. He who was a Roman or a Frank is now a Galilean, or an inhabitant of Palestine. One who was a citizen of Rheims or of Chartres now has been made a citizen of Tyre or of Antioch. We have already forgotten the places of our birth; already they have become unknown to many of us, or, at least, are unmentioned. Some already possess here homes and servants which they have received through inheritance. Some have taken wives not merely of their own people, but Syrians, or Armenians, or even Saracens who have received the grace of baptism. ... One cultivates vines, the other the fields. . . . Different languages, now made common, become known to both races, and faith unites those whose forefathers were strangers. ... He who was a foreigner now is a native; and he who was a sojourner now has become a resident. Our parents and relatives from day to day come to join us. ... For those who were poor there, here God makes rich. Those who had few coins, here possess countless bezants; and those who had not had a villa, here, by the gift of God, possess a city. Therefore, why should one who has found the East so favorable return to the West? ... You see, therefore, that this is a great miracle, and one which must greatly astonish the world. Who has ever heard anything like it? (History 271-72) ${ }^{3}$

Who has heard anything like this? Those of us in the academy who work in postcolonial studies, of course, have heard this before, albeit not issued as a twelfth-century paean of exultation. The legacy of European maritime empires of the early and high modern eras makes the details of colonial occupation to which Fulcher bears witness startlingly familiar: the expropriation of land and resources; the creation of colonial elites, a subject class ("servants"), and intergenerational transfers of colonial privilege ("inheritance"); a mystified politics of language and of sexual and ethnoracial relations; even the pleasures of going native and complacent self- congratulation by colonial masters secure in the rightness of their destiny.

A critical strain in medievalist scholarship has acknowledged the Crusades as twelfth-century colonial experiments in extraterritoriality. "Here was made the first step of teaching Europe how to colonize," said the redoubtable Joshua Prawer: an early model of the European colonial experience rooted in territorial occupation and political dominion, economic extraction, ideological reproduction, and evidence of a "colonial mentality" and colonial relations, legible in the records of the occupied territories of the Levant (366). "At their peak," Josiah Russell noted, "the crusading states controlled about three fifths of the land and population of Syria" (56).

Additionally, despite the eventual loss of all territories in Syria and Palestine after two centuries, Europe's adventurism shifted the economic calculus of early capitalism in favor of the Latin West. By transferring agricultural, industrial, engineering, and other knowledges from the Levant and Littoral, crusader colonization proved a crucial hinge not only for the growth of European industries, agriculture, architecture, and artisanry but also for remaking the balance-ofpayments calculus between East and West: so that by the end of the Middle Ages the East came to assume the erstwhile role of the West, exporting far more raw materials than manufactures, in an ironic reversal of their trade roles early in the Middle Ages. ${ }^{4}$

How the dominance of Islamicate and Greek societies was eroded in export industries like sugar, textiles, and even fine, transparent glass is well documented. Indeed, the economic consequences of the twelfthcentury transfer of glass-blowing technologies from Tyre to Venice can still be seen in the twenty-first century: today it is Venice's exquisite Murano glass, not Lebanese Tyrian glass, that is globally renowned and collected. As William Phillips wryly observes in his study of sugar production, while "the Crusades may 
have failed ... in economic terms they were successful, as the West wrested economic ascendancy from the East" (403).

That extraterritorial experiment we know as the Crusades thus offers a dramatic example of how a view across the longue durée is valuable for postcolonial and global studies. In a short essay like this I cannot, of course, adequately adduce the many gains to be had by enlarging our framework of time to grant access to the deep past. But I will focus on four examples to suggest briefly how the investigation of colonization, race, and global modernity across macrohistorical time can elicit a spectrum of corrective, elucidative, or transformative perspectives and models for colonial, postcolonial, and global studies in the academy today.

\section{Recovering Early Literatures of Colonization}

Pushing back the chronological parameters of postcolonial studies to embrace a longer durée admits into circulation narratives like Fulcher's, where familiarity and surprise jostle together queerly in the reader's experience. What is gained by recovering such early literatures of colonization? For one thing, reading Fulcher's colonial now alongside the now of later colonizations in an enlarged temporal horizon makes us alive to the resilience and tenacity of colonial dialect. The parsimony of colonial dialect-its deft mystification of the relations of power, as it takes on coloration apposite to time and place-is remarkably instructive.

Equally instructive is the necessity to adjust and refine the operational authorizations of colonial dialect in each historical instantiation. When Guibert de Nogent, the learned abbot of Nogent-sur-Coucy, writing his own crusade chronicle from his perch in twelfthcentury France, calls occupied Jerusalem a "new colony" ("novae coloniae") of Christendom, he self-consciously evokes imperial Rome as a predecessor, in whose magisterial footsteps Christendom would now follow (4: 245). Yet the very evocation of the Roman Empire as an exemplar registers the twelfthcentury West's engagement in colonialism as de facto neocolonialism, as crusader colonization becomes, in the rhetoric of the abbotideologue-apologist, "Gesta Dei per Francos," the deeds of God through the medium of the Franks. A reinvention that inserts a difference by invoking religion, now, and God as the authorizing discourse of its colonial enterprise, crusading militarism sets in place a creolized template of colonization indispensable to the later European colonial expeditions that would arrive-not like Rome, but like Christendom-wielding the sword and the Book.

For those of us who study the longue $d u$ rée wherein inventions and reinventions of colonization, race, and globalisms recur, the imperative thus is always to hold to a dialectical vision that allows for the recognition of historical recurrence across the longue durée and of differences in specific articulations that effloresce in historical time and place.

That imperative issues a simple exhortation: do not see historical time as a linear progression from premodernity to modernity fissured by a break, but instead view history as offering repetitions with change (the twelfth-century West making new and hybridizing the example of Roman colonization) or historical time as oscillating between ruptures and reinscriptions and embedding multiple temporalities within each historical moment. For postcolonial studies, race studies, and critical global studies, the gains to be had, I have argued elsewhere, are substantial. ${ }^{5}$

\section{Reading Race across Macrohistorical Time}

With a long historical view, race theory gains the ability to name laws, acts, practices, and institutions in premodernity for what they are and to grasp the ramifications of what they install, to see the long arc of racial instantiations. The study of racial emergence 
à la longue durée is then one means to understand if the configurations of power that produce race in modernity are, in fact, genuinely novel. Key propensities in history can be identified, not over a century or two but across a millennium: the modes of apparent necessity, configurations of power, and conditions of crisis that witness the harnessing of powerful dominant discourses-science in the era of high modernity, religion in the socalled Middle Ages - to make fundamental distinctions among humans to which we give the name of race.

For instance: before the consolidation of a language of race, in a period when Jewish finance and its credit system drove the engine of economic modernity in Europe, and when countries in the West began the long process of imagining themselves as political communities bordered by territorial boundaries, a multiplicity of instruments and micropowers converged to make England into the first racial state in the history of the West. ${ }^{6}$

English Jews were forced by law in 1218 to wear a badge on their chest that distinguished them from the Christian population, in the first example of a country's execution of canon 68 of the Fourth Lateran Council of 1215, which mandated that Jews and Muslims be set apart from Christians by a difference in dress. In 1222, 1253, and 1275 English rulings elaborated on this badge-who had to wear it (first men and women, then men, women, and children over the age of seven), as well as its size, its color, and how it was to be displayed on the chest in an adequately prominent fashion. In 1290, after a century of legislature that eroded the economic, religious, occupational, social, and personal status of English Jews, Jewish communities were driven out of England en masse, marking the first permanent forcible expulsion of Jews in Europe. ${ }^{7}$

Scientific, medical, and theological treatises argued that the bodies of Jews differed in nature from those of Christians: Jewish bodies gave off a special fetid stench (the in- famous foetor judaicus), and Jewish men bled uncontrollably from their nether parts, either annually, during Passion Week, or monthly, like menstruating women. Some authors held that Jewish bodies came with horns and a tail, and popular belief circulated for centuries through the countries of the Latin West that Jews constitutionally needed to imbibe the blood of Christians, especially little boys, whom they ritually mutilated, tortured, and crucified-an accusation of Jewish murder of children that began in England in 1144 and spread thereafter to France, Germany, Spain, Italy, and elsewhere (Hillaby 98-102).

England's treatment of Jews, the historian Robert Stacey notes, was "archetypical" of how Jews were treated throughout Europe, differing mainly by virtue of the earliness, inventiveness, and intensity of English actions (“Jews" 340). A special subset of government known as the Exchequer of the Jews was created to monitor the lives of Jews, who had to document all economic activities at special registries that tracked their assets: no business could be lawfully transacted except at these registries, which came to determine where Jews could earn a living.

English Jews needed permission and licenses to establish or to change their residence, and by 1275 , after a series of statutes, ordinances, and decrees, the Statutum de Judeismo dictated that they could not live in any city without a registry by which they could be scrutinized and that they could not have Christians living in their midst-a thirteenth-century experiment in segregation that effectively created the medieval ghetto.

England's Jews were also subjected to fiscal extortions and special taxations that milked them to the edge of penury. They were barred from marriage with Christians, from holding public office, from eating with Christians or lingering in Christian homes, from walking publicly in city streets during Holy Week, and even from praying too loudly in synagogues. Conversionist sermons were 
preached at them, and, in 1232 , the state established the Domus Conversorum in London to house converted Jews, financed by taxes from unconverted Jews.

Jews were also subjected to periodic extermination by Christians: in 1189, they were slaughtered at Westminster, London, Lynn, Norwich, Stamford, Bury Saint Edmunds, and York. The constraints on their lives are too numerous to list; some would resonate eerily with the treatment of minority populations in racial states of other eras, linking into relationship medieval and modern time. I have argued that these and other practices amount to de facto race making: producing phenomena, institutions, laws, and behavior that deserve to be named as racial. ${ }^{8}$

For race theory, a reissuing of the medieval past in a long temporal vision that admits the interplay of the past with the present only recalibrates the urgencies of the present with greater precision: religious race, so much in evidence during the Middle Ages in Europe's response to Jews, Muslims, and others, has reemerged as a force again today. ${ }^{9}$ Investigating the invention of race in medieval Europe also calls for grasping the ways in which Homo Europaeus - the European subject-emerges through racial grids produced from the twelfth through fifteenth centuries, and the significance of that emergence for understanding the unstable entity we call "the West" and its self-authorizing missions across macrohistorical time. ${ }^{10}$

\section{Seeing Modernities in Premodernity; Plural Industrial-Scientific Revolutions}

For global studies, recognition that the deep past unevenly manifests what we today consider indices of modernity secures disciplinary commitment to a critical global studies. This is because time across the globe $a$ la longue durée ineluctably imparts the recognition that modernity itself is a repeating transhistorical phenomenon, with a footprint in different vectors of the world moving at different rates of speed. One example is China: seven hundred years before Western Europe's "Industrial Revolution," the tonnage of coal burned annually in eleventh-century Song China for iron and steel production was already "roughly equivalent to $70 \%$ of the total amount of coal used by all metal workers in Great Britain at the beginning of the 18th century" (Hartwell, "Cycle" 122; see also Hartwell, "Revolution"). Mass-market industrial production of ceramics in China's Fujien Province and elsewhere for export to the world also occurred centuries before similar commercial mass production in the West (So, esp. 186-201).

Global temporalities thus impel recognition of more than a single scientific or industrial "revolution" and more than a single geographic locale ("the West") as the instantiating matrix. Study of the global past invites critical responses to the foundational history of the present-decentering tenacious narratives of an exceptional European genius, essence, climate, mathematical aptitude, scientific bent, or other environmental, philosophical, or cognitive factors guiding destiny in "the rise of the West." " And Europe is always already provincialized: a provincializing activated $a b$ origo by virtue of the focus on multifarious locales centuries before even the consolidation of Europe as a corporate entity.

Because premodern China's history attests to the difficulty of building on technological and scientific innovations in the context of repeated territorial invasion and political and social disruption, China's example also importantly restores an acknowledgment of the role of historical contingency-chance, not destiny-as a principal determinant in civilizational history. China's precocious modernities within premodernity also guide an understanding of the plurality of time-of temporalities that are enfolded and coextant within a single historical moment-that helps to make intelligible not only 
premodern worlds but also societies today around the globe, which can seem modern, postmodern, and premodern all at once.

Most important, studying the global in deep time undercuts the fantasy that an earlier Europe was the opposite of Europe today, a continent that contains global populations from everywhere. Early globalisms bear witness to a medieval Europe that was already contaminated by the presence of people from everywhere-Jews, Arabs, Turks, Africans, Mongols, "Gypsies," steppe peoples, and others-and refuse the fiction that a singular, homogenous, communally unified Caucasian ethnoracial population once existed in Europe. The notion that a "white" Europe existed as a historical inheritance-not as a concept manufactured by centuries of assiduous identity construction-is thus exposed as the fantasy of contemporary European politics and political factions. ${ }^{12}$ The study of the global past in deep time thus productively speaks to the racial politics of the contemporary European now.

\section{Old Stories Make New Comparative Literature; or, Global Literatures avant la Lettre}

I end my example-driven arguments with a literary example of what global studies might glean from a world-traversing story when we follow its two-thousand-year arc across the planet.

In the vast corpus of the story's materialization, the plot goes like this: a young prince of India is secluded in luxury by his anxious royal father, after an alarming prophecy at the prince's birth, and grows up in a sheltered palatial cocoon. Yet the prince somehow manages to encounter human misery in the form of old age, disease, and death. After a series of pivotal events, lessons, and reflections, he renounces worldly life and turns to asceticism as the answer to human tribulation and suffering. After his death, the prince becomes the world's most renowned exemplar of pacifist asceticism.
The story of Siddhartha Gautama (fl. sixth or fifth century BCE) - the Buddha-is an extraordinary allegory of global multilingual encounter and translatio: of how mobilities of plot, names, ideas, motifs, and themes, traveling across the planet in a dynamic web, were transacted through traceries of exchange, borrowing, and remaking that are still in the process of being discovered. The story fans out from early Sanskrit and Pali (Mahayana and Theravada) accounts, most notably the Buddhacarita of Asvaghosha (the earliest full biography, stemming from the second century CE), the Lalitavistara Sutra (of the third century CE), and folklore-like Jataka tales (the traditional canon of which consolidated around the fourth and fifth centuries CE).

In the northward and westward push of narrative (there's also an eastward spread), scholarship has surmised a multilingual pathway from India to the West, through Central Asia, where story fragments were found in Manichaean manuscripts (eighthcentury copies of which were discovered in Chinese Turfan); then into recensions in Arabic; thereafter into Georgian; then transposed from Georgian to Greek in the early eleventh century by the Georgian founder and abbot of the Iviron monastery of Mount Athos, Saint Euthymius; and then from Greek into Latin, the earliest version of which, from the mideleventh century, has been traced to Naples. The forest of vernacular texts that sprang up thereafter in Europe was seeded by the second Latin version, of the late eleventh and twelfth centuries (other Latin versions, long and short, exist). Vernacular texts have appeared in Germany, France, the Netherlands, Romania, Provence, Italy, Spain, Norway, Portugal, Russia, and England. There are Ethiopic and Armenian versions, and a Filipino version appeared in the eighteenth century.

Astonishingly, in the course of global translatio, the Buddha's story morphs into a Christian story, in which the central protagonist splits into two characters: 
a teacher-eremite called Balaam, and his prince-student, called Josaphat (the orthography of the names varies). Christian sainthood has been conferred on these exalted doppelgänger twins, whose joint feast day in the Roman martyrology of 1584 , commissioned by Gregory XIII, is 27 November.

How the Buddha grew the name Josaphat or Iosaphat is a stunning micrological specimen of global translatio's spoor. From Sanskrit descriptions of him as a bodhisattva, the enlightened Indian prince is called the Bodisav in Manichaean fragments (Almond 404-05); Bodhisattva (Bwdysdf) is even among the titles given to Mani in Middle Iranian hymns (Lang 25). In Arabic recensions, the honorific becomes Budhasaf and from a scribal slip emerges as Yudhasaf (Lang 29): "Because the Arabic B and Y differ by only a single diacritical point, Budhasaf by virtue of a scribal error became Iodasaph in Georgian, Ioasaph in Greek, and finally Josaphat in Latin" (Almond 395).

In the geographical round of how a name morphs, we catch a glimpse of early globalisms-stories and texts traveling with merchants and caravans, monks and scribes, envoys and artisans, soldiers and slaves, the retinues of exogamous brides-that end up planting the Buddha as "a saint in Christendom for some nine hundred years" (Almond 395). ${ }^{13}$ A Christian Buddha materializes as a literary entrepôt of early globalism.

Why the Buddha transforms into a Christian and splits into two characters is another allegory of globalism. More important than the mere fact that objects and stories circulate is how their meaning creolizes or, conversely, why certain elements remain intransigent, impervious to change. ${ }^{14}$ Buddha or Christian saint(s), some things continue to hold up: the role of women and female sexuality, for instance, proves perennially instrumental. Also of durable commitment are homosocial narrative trajectories and persistent models of desire and threat.
While scholars commonly focus on the pull of moral-metaphysical instruction the story enacts, key elements of story also dramatize resistance to power and authority, stage critiques of corruption, and offer celebrations of evasion and concealment that embed sociopolitical attractions that no doubt helped to drive the story's global motility. A story's talent in cultivating multiple audiences for millennia suggests it affords pleasures and instrumentalities of many kinds.

How societies reissued this global artifact's meaning for themselves-what each cultural geolocation wanted from its peripatetic, flexible, and accommodating narrative-perhaps only future work in global studies will adequately disclose. Involving so massive a web of texts, languages, dialects, crossings, and traces that it beggars by comparison Franco Moretti's scholarly target-the novel as world literature (Graphs) - the kind of world literature represented by the story of Balaam and Josaphat as it arcs across millennia, foresting the world with literary texts, calls for wide and deep collaboration among comparatists of literature and between scholars of literature and those of other disciplines, combining methods, periods, and fields.

In urging literary and transdisciplinary collaborations, our last premodern example from the longue durée-an uncanny Christian Buddha-perhaps also traces one more future for postcolonial and global studies. ${ }^{15}$

\section{NOTES}

1. This short essay cannot provide comprehensive documentation, but since my examples emerge from work undertaken elsewhere, I point to that work for fuller documentation and bibliographies. E.g., for a discussion of the First Crusade, eyewitness Latin chronicles, and the genesis of romance in twelfth-century Europe from crusader cannibalism and traumatic encounters with the East, see my Empire of Magic. "Deep time" is Dimock's formulation, adapted from the physical sciences.

2. For the original, see «Liber» 150. 
3. For the original, see Historia 748-49. I have slightly modified the translation.

4. See, e.g., Abu-Lughod; Ashtor, "Economic Decline," Social and Economic History, "Levantine Sugar Industry," and Levant Trade; Heck; Phillips. Laura Doyle's essay in this cluster shows how the rise of European markets and cities is underwritten by "hydraulic projects" developed earlier in Islamicate societies and transferred inter-imperially to the West.

5. Heng, "Holy War Redux," "Invention of Race ... 1," "Invention of Race .. . 2," and "Early Globalities."

6. While transhemispheric inter-imperiality and globalism powered economic modernities around the world, within European countries economic activities-whether the cultivation of arable land or the building of cathedrals, the outfitting of merchant ships or preparations for wardepended heavily on Jewish financing. Foreign-exchange manipulations could sometimes disguise loans, but ecclesiastical prohibitions against "usury" by Christians meant that the widespread credit system created by Jewish financing was indispensable to all strata of society. Indeed, in England, land held in security for Jewish loans changed hands so rapidly from traditional landowners to new, upstart classes and religious houses that the state enacted legislature prohibiting loan-related land transfers, which were transforming the feudal economy (Stacey, "Jewish Lending"; Mundill 36-37; Roth 52, 107; Richardson 90-103, 108; Pollins 17).

7. The literature on English Jews is vast. Adler; Richardson; Roth; and Mundill offer some points of entry. I provide comprehensive references in "England's Dead Boys."

8. A long historical view thus points to that friendly compound "Judeo-Christian" as a novel, modern, indeed post-Shoah catachresis. Goldberg discusses the racial state in modernity.

9. In "Holy War Redux" I discuss how a racial strategy visited on medieval Jews is redeployed today against Muslims, most infamously in Bernard Lewis and Samuel Huntington's "clash of civilizations" thesis.

10. The book I am completing, "The Invention of Race in the European Middle Ages," treats Europe's encounters with Jews, Muslims, Africans, Native Americans, Mongols, and "Gypsies."

11. For recent responses to grands récits of the "rise of the West," see, e.g., Goldstone; Hart, "Great Explanandum." Hart's Chinese Roots of Linear Algebra puts a dent in theories of a unique European genius for mathematics.

12. I track the ascent of whiteness to centrality in European identity construction in "African Saint."

13. See Sahar Amer's essay in this cluster on how stories migrate.

14. Glaire Anderson's essay in this cluster describes how a single word inscribed on tenth-century Islamicate bronze bowls shifts in meaning as it encircles the world.

15. Moretti's critique of comparative literature as an enterprise that "has not lived up to its beginnings" because it's been "fundamentally limited to Western Europe," and his exhortation to study world literature, emphasizes the necessity of forging new pathways in scholarship: "The question is not really what we should do-the question is how" ("Conjectures" 54-55). We may see collaboration as one answer to his "how," especially in the study of multilingual global texts à la longue durée.

\section{Works Cited}

Abu-Lughod, Janet L. Before European Hegemony: The World System, A.D. 1250-1350. New York: Oxford UP, 1989. Print.

Adler, Michael. Jews of Medieval England. London: Jewish Hist. Soc. of England, 1939. Print.

Almond, Philip. "The Buddha of Christendom: A Review of the Legend of Barlaam and Josephat." Religious Studies 23.3 (1987): 391-406. Print.

Ashtor, Eliyahu. "The Economic Decline of the Middle East during the Later Middle Ages: An Outline." Technology, Industry, and Trade: The Levant versus Europe, 1250-1500. Ed. B. Z. Kedar. Brookfield: Variorium, 1992. 253-86. Print.

- Levant Trade in the Later Middle Ages. Princeton: Princeton UP, 1983. Print.

_. "Levantine Sugar Industry in the Late Middle Ages: A Case of Technological Decline." The Islamic Middle East, 700-1900. Ed. A. L. Udovitch. Princeton: Darwin, 1981. 91-132. Print.

- A Social and Economic History of the Near East in the Middle Ages. Berkeley: U of California P, 1976. Print.

d'Aguiliers, Raymond. Historia Francorum qui ceperunt Iherusalem. Trans. John H. Hill and Laurita L. Hill. Philadelphia: Amer. Philos. Soc., 1968. Print. Memoirs of the Amer. Philos. Soc. 71.

_ L L «Liber» de Raymond d'Aguilers. Ed. John Hugh Hill and Laurita L. Hill. Paris: Geuthner, 1969. Print.

Dimock, Wai-Chee. Through Other Continents: American Literature across Deep Time. Princeton: Princeton UP, 2006. Print.

Fulcher of Chartres. The Chronicle of Fulcher of Chartres. The First Crusade: The Chronicle of Fulcher of Chartres and Other Source Materials. Ed. Edward Peters. Trans. Martha E. McGinty. Philadelphia: U of Pennsylvania P, 1971. 47-101. Print. Middle Ages Ser.

—. Historia Hierosolymitana (1095-1127). Ed. Heinrich Hagenmeyer. Heidelberg: Winters, 1913. Print.

- A History of the Expedition to Jerusalem, 10951127. Ed. Harold S. Fink. Trans. Frances Rita Ryan. Knoxville: U of Tennessee P, 1969. Print.

Gesta Francorum et aliorum Hierosolymitanorum: The Deeds of the Franks and the Other Pilgrims to Jerusalem. Ed. and trans. Rosalind Hill. Oxford: Clarendon, 1962. Print. 
Goldberg, David Theo. The Racial State. Malden: Blackwell, 2002. Print.

Goldstone, Jack A. "Efflorescences and Economic Growth in World History: Rethinking the 'Rise of the West' and the Industrial Revolution." Journal of World History 13.2 (2002): 323-89. Print.

Guibert de Nogent. Gesta Dei per Francos. Paris: Académie des Inscriptions et Belles-Lettres, 1879. Print. Pt. 2 of vol. 4 of Historiens occidentaux. Recueil des historiens des croisades 2 .

Hart, Roger. The Chinese Roots of Linear Algebra. Baltimore: Johns Hopkins UP, 2010. Print.

_. "The Great Explanandum." American Historical Review 105.2 (2000): 486-93. Print.

Hartwell, Robert. "A Cycle of Economic Change in Imperial China: Coal and Iron in Northeast China, 7501350." Journal of the Social and Economic History of the Orient 10 (1967): 102-59. Print.

—. "A Revolution in the Chinese Iron and Coal Industries during the Northern Sung, 960-1126 A.D." Journal of Asian Studies 21.2 (1962): 153-62. Print.

Heck, Gene W. Charlemagne, Muhammad, and the Arab Roots of Capitalism. Berlin: De Gruyter, 2006. Print.

Heng, Geraldine. "An African Saint in Medieval Europe: The Black Saint Maurice and the Enigma of Racial Sanctity." Sainthood and Race: Marked Flesh, Holy Flesh. Ed. Vincent Lloyd and Molly Bassett. New York: Routledge, 2014. 18-44. Print.

. "Early Globalities, and Its Questions, Objectives, and Methods: An Inquiry into the State of Theory and Critique." Exemplaria 26.2-3 (2014): 232-51. Print.

- Empire of Magic: Medieval Romance and the Politics of Cultural Fantasy. New York: Columbia UP, 2003. Print.

_ _ "England's Dead Boys: Telling Tales of ChristianJewish Relations before and after the First European Expulsion of the Jews." MLN 127.5 supp. (2012): 5485. Print.

- "Holy War Redux: The Crusades, Futures of the Past, and Strategic Logic in the 'Clash' of Religions." PMLA 126.2 (2011): 422-31. Print.

. "The Invention of Race in the European Middle Ages 1: Race Studies, Modernity, and the Middle Ages." Literature Compass 8.5 (2011): 315-31. Web. 28 Apr. 2015.

—. "The Invention of Race in the European Middle Ages 2: Locations of Medieval Race." Literature Compass 8.5 (2011): 332-50. Web. 28 Apr. 2015.
Hillaby, Joe. "The Ritual-Child-Murder Accusation: Its Dissemination and Harold of Gloucester." Jewish Historical Studies 43 (1994-96): 69-199. Print.

Lang, David Marshall. The Wisdom of Balahvar: A Christian Legend of the Buddha. London: Allen, 1957. Print.

Moretti, Franco. "Conjectures on World Literature." New Left Review 1 (2000): 257-94. Print.

- Graphs, Maps, Trees: Abstract Models for a Literary History. London: Verso, 2005. Print.

Mundill, Robin. England's Jewish Solution: Experiment and Expulsion, 1262-1290. New York: Cambridge UP, 1998. Print.

Phillips, William D., Jr. "Sugar Production and Trade in the Mediterranean at the Time of the Crusades." The Meeting of Two Worlds: Cultural Exchange between East and West during the Period of the Crusades. Ed. Vladimir P. Goss and Christine Verzár Bornstein. Kalamazoo: Medieval Inst., 1986. 393-406. Print. Studies in Medieval Culture 21.

Pollins, Harold. Economic History of the Jews in England. East Brunswick: Associated UPs, 1982. Print.

Prawer, Joshua. The Crusaders' Kingdom: European Colonialism in the Middle Ages. New York: Praeger, 1972. Print.

Richardson, Henry Gerald. The English Jewry under Angevin Kings. London: Methuen, 1960. Print.

Roth, Cecil. A History of the Jews in England. Oxford: Clarendon, 1941. Print.

Russell, Josiah. "Demographic Factors of the Crusades." The Meeting of Two Worlds: Cultural Exchange between East and West during the Period of the Crusades. Ed. Vladimir P. Goss and Christine Verzár Bornstein. Kalamazoo: Medieval Inst., 1986. 53-58. Print. Studies in Medieval Culture 21.

So, Billy K. L. Prosperity, Region, and Institutions in Maritime China: The South Fukien Pattern, 947-1368. Cambridge: Harvard UP, 2000. Print.

Stacey, Robert C. "Jewish Lending and the Medieval English Economy.” A Commercialising Economy: England, 1086 to c. 1300. Ed. Richard H. Britnell and Bruce M. S. Campbell. Manchester: Manchester UP, 1994. 78-101. Print.

. "Jews and Christians in Twelfth-Century England: Some Dynamics of a Changing Relationship." Jews and Christians in Twelfth-Century Europe. Ed. Michael A. Signer and John Van Engen. Notre Dame: U of Notre Dame P, 2001. 340-54. Print. 